\title{
A Review on photovoltaic poverty alleviation projects in China: conjunctures, current status and policy recommendations
}

\author{
Peishi $\mathrm{Wu}^{1, *}$, Siyu $\mathrm{Ke}^{2}$, and Yiling Gao ${ }^{1}$ \\ ${ }^{1}$ Beijing Normal University - Hong Kong Baptist University United International College, 2000 Jintong Road, Tangjiawan, Zhuhai, \\ Guangdong Province, China \\ ${ }^{2}$ Agriculure-Forest Economic Management, School of Management, Hainan University, 58 Renmin Avenue, Meilan District, Haikou \\ City, Hainan Province, China \\ "E building, School of Environment and Energy, Shenzhen Graduate School of Pecking University, Shenzhen, China
}

\begin{abstract}
Photovoltaic-based targeted poverty alleviation (PVPA) has been established for 10 years with the mission of one of "the ten large-scale poverty relief programs" in China. This paper would firstly examine the historical conjuncture of the PVPA, followed by the current status and the analysis of policy instruments. Results show that there are mainly three categories of policy instruments: the supply-type ones, the environment-oriented ones and the demand-type ones, with the previous two emphasized. The three most popular policy instruments that governments prefer to use are goal planning, financial support and infrastructure construction. Despite the great achievements, PVPA also need some improvements to be better implemented, and in the last part of the paper, some policy implementations are made regarding the unbalance distribution of the instruments among three above-mentioned classifications, as well as financial issues and accountability factors. It is suggested that governments should pay more attention to the demandtype policy instruments such as procurement or encouragement of the PV power generated by PVPA projects, and at the same time find better ways to supervise the benefit distribution.
\end{abstract}

\section{Introduction}

In the past five years, China has witnessed great progress of the targeted poverty alleviation under President Xi Jinping's poverty relief proposal. The impoverished number has declined over 60 million and the total poverty rate has decreased from over $10 \%$ to less than $4 \%$. However, continuously working on targeted poverty alleviation is still a crucial goal for the central government with great difficulties.

China has abundant solar radiation, and more than $66 \%$ of the Chinese landscape enjoys over 2000 sunshine hours per year, which provide quite satisfied conditions for the PVPA projects [1]. The Poverty Relief Office of State Council named the PVPA one of the "ten targeted poverty alleviation programs" which is a preferable approach to both central government and local government for its characteristics of income stability, energy saving and Green House Gas emission elimination. Practically speaking, farmers can use the green power generated from the PVPA projects and sell the surplus to the national grid with subsidiaries to earn some extra income. This project could help both the poor families owning the PV stations and the PV manufacturers, since the latter party could earn profit by selling the PV station component and maintenance \& operation parts. The win-win situation could finally stimulate the regional GDP.
To successfully realize the PVPA projects, supporting policies plays a crucial role, therefore how to design the policy in a proper way has been a issue of great significance. At present there are mainly three categories of policy instruments namely supply-type, environmentoriented and demand-type policy instruments, with distinguished features and bias, which could be useful in different situations. Thanks to the policy instruments, some PV enterprises have gained great progress in the PVPA projects and there are quite a lot of positive role models. However, the targeted poverty alleviation also faces some noticeable difficulties in its development, especially in the policy-making decisions, including the unbalance development of the different categories of policies and other lack of demand and financial support polices, thus there are some policy implementations at the end of the paper to give some future possibilities.

\section{LITERATURE REVIEW}

According to $\mathrm{Oh}$ and Yoo, applying and encouraging the green energy in developing countries could be a feasible way to increase the household income of the povertystricken population, and at the same time, improve the renewable technologies as well as the local GDP $[2,3]$. This notion has been widely accepted by a number of

*Corresponding author: wupeishi@pku.edu.cn 
scholars [4-9]. However, the literatures directly mentioned about PVPA projects are rare with no systematic research so far.

In fact, if any kind of poverty alleviation needs to gain certain achievement, several conditions must be met first including technical support, infrastructure construction, education and support policies. Liu and Li emphasized that to fulfill the previous requirements, some actions shall be taken such as boosting the tourism industry, establishing more educational institutes, continuously improve the local infrastructure and collecting large amount of dataset [10]. Li, at the same time, emphasized the significance of agricultural science in rural areas [11]. According to Jennifer and Smallholder, the popularity of small-sized irrigation technology can noticeably enhance the grain harvest and therefore help the poverty-stricken population out of poverty [12].

Education and labor training are also long-term mechanisms for the poor population to escape poverty. For example in mining industry, Ge and Lei did a study a concluded that education and training could effectively and efficiently enhance the possibility for poor people to increase their household income to meet the povertyrelief benchmark [13].

Evidently, although there are a lot of studies regarding poverty relief, papers directly related to PVPA is still deficient. Therefore, a study regarding PVPA and policy recommendations could be helpful to governments to make further decisions.

\section{PVPA CONJUNCTURES STATUS}

\subsection{Why PVPA now?}

To better understand the current status and the political support regarding PVPA projects in China, we should firstly study the historical conjectures and drivers of this particular policy category - why launched PVPA at that specific period of time? In this paper, three factors are illustrated in the following section: the stubborn poor situation in the rural areas in China, demonstrating the demand of extra income for the poverty-stricken people; the crossroad of Chinese PV industry due to the overcapacity and curtailment, leading to the urgent need of distributed PV installation; and last but not least, the poor coverage of electrification in poor areas in China.

\subsubsection{The poverty situation in rural areas}

Since the market reform and openness policy in 1978, 29 years after the founding of new People's Republic of China, this country experienced a period of remarkable, even unprecedented economic development, witnessing an average annual growth rate of around $10 \%$ over the past 30 years, and the household income as well as the per capita GDP increased dramatically in both urban and suburban areas, lifting more than 800 million people successfully out of poverty [14].

Nevertheless, the uneven development in the household income and other living standard benchmarks between rural areas and urban areas is greater than ever. For example, the average per capita disposable income in urban areas rose from $343 \mathrm{RMB}$ in 1978 to $31,195 \mathrm{RMB}$ in 2015, while the average per capita disposable income in rural areas increased from $134 \mathrm{RMB}$ to $11,422 \mathrm{RMB}$ during the same time span [15]. Throughout the whole process of the reform and openness era, the urban-rural income ratio in China was around $3: 1$, much higher than the international average ration of around 1.5:1 [16], not mention the non-monetary variances in a lot of other important areas such as education level, industrial level, social welfare, medical care and other gaps. Besides, this urban-rural income gap is not distributed evenly in China as well. The situation is especially severe in western regions where the natural resources are quite limited and the climate is not suitable for the development of most industries. In fact, the urban-rural income gap ratio could reach as high as 4:1 in some western provinces [17]. According to China's official figure for the current poverty standard (2300 RMB of annual per capita income), the poverty population in China was around 56.30 million in rural areas in the year of 2015 [18], most of which were staying in western provinces.

Ever since President $\mathrm{Xi}$ Jinping came to power in the year 2012, the poverty issue and the unbalanced development in China had been elevated to one of the highest priorities during the process of development in China [19]. Under Xi's spirit, several policies has been issued after Xi's visits to the poorest areas in China, echoing his determination in the battle of poverty [20]. After a few years' trial and error, the current poverty alleviation projects in China mainly focuses in two major criteria: the so-called "precision" and "industrial" requirements. The former one emphasized that the government should make sure to target the real poor households according to some precise and comprehensive data with multiple-phase re-classification system, and the latter one aimed to help the poor households to improve a certain technique by developing innovative industrial facilities, so that these households could reach a self-sustainable development in the long run. PVPA projects could perfectly match the two requirements simultaneously [19].

\subsubsection{The current status of China's solar energy industry}

The second main reason why the PVPA projects have been launched is the industry itself. China enjoys the relatively low cost of labor and raw material expenditures in the PV industry thus has experienced an incredible boost in the manufacturing section in the PV industry around ten years ago, making China one of the largest export entities in solar PV products [21-23]. 
However, the unexpected sudden shrink of the global demand thanks to the financial crisis as well as the antidumping and anti-monopoly execution in the year 2011 by the western world pushed the Chinese PV industry into the winter period $[24,25]$.

Therefore, China's central government decided to establish a series of encouraging policies to stimulate the domestic PV market as a rescue strategy including feedin-tariff, subsidies, pilot program, biding projects and so on, as a top-down manner to widen and recover the Chinese PV industry, especially the manufactory sector [26].

This stimulation strategy earned a huge success indeed. By the year 2013, China has surpassed other countries to be the world's leading market in terms of total PV installation, reaching $43.18 \mathrm{GW}$ by the end of $2015[27,28]$, with over $15 \mathrm{GW}$ new installation in the single year of 2015 [29]. Nevertheless, the manufacturing capacity grew even faster. As a matter of fact, the domestic newly installation of $15 \mathrm{GW}$ in the year of 2015 only consumed approximately $30 \%$ of the national production of PV panels, leading to a serious and persistent over-capacity in the long run $[27,28]$.

Furthermore, and curtailment issue is rampant due to the unbalance development of PV station installation and the grid connection efficiency. Most of the new capacity installation is currently established in the poor western areas where the electricity consumption is low and the transmission cost is high [30]. The curtailment rates had reached as high as $25 \%$ in western provinces such as Gansu and Xinjiang in 2015 and this ratio has climbed to as high as $39 \%$ over the first half year of 2016 [27,28]. Then the central government adjusted its policy to control the over-development of the centralized PV station installation by stimulating the distributed ones where the electricity generated could be consumed locally at first [31-33]. The distributed PV systems have been welcomed by Chinese government for a long time and viewed as the best model in China. However, from the investor's point of view, the centralized large-scale PV stations is undoubtedly the more favorable one with stable cash flow and remarkable IRR, thus $90 \%$ of the investment capital flew into the large scale projects in the year 2015 [33]. The distributed ones, however, are continuously under the government's expectation therefore the PVPA projects could be an idea product under this situation, which can simultaneously receive the support from both the environmental perspective and the poverty-alleviation one.

\subsubsection{Rural electrification tendency}

To better understand the PVPA projects, not only the poverty alleviation target and the PV stations should be taken into consideration, the development of the electrification history in China should also be demonstrated.

At the founding of the new China in the year 1949, less than $10 \%$ of the Chinese residents could access to electricity, thus expanding electrification became one of the most important of the political target for the central government. By the year 2013, this figure had reached as high as $99.8 \%$ [34], and the last 39,800 people in the most remote areas in Qinghai Province were reported successfully connected, meaning China has finally reached the $100 \%$ electrification standard. But the problem behind the issue is apparent as well: the Chinese central government has spent over US $\$ 4$ billion on this policy and this is not a efficient and suitable policy in the long run.

To cope with the electrification target as well as the environmental concern, the renewable energy played an increasingly important role in the electrification process in the remote and poverty areas, and the dominant choice was small hydro power (SHP) stations in China for a long time, reaching $73 \mathrm{GW}$ by the end of 2014 thanks to the 47,000 SHP stations in China, occupying more than $25 \%$ of the total hydropower capacity of the whole country $[35,36]$. Different from the PV stations, the SHP stations enjoys bottom-up approach policies so that the local government, investors and local residents had enough intention to build them [37].

However, the construction of the SHP stations has been slowing down since 2012 due to the lack of new suitable spots with hydro potential. As a result, the solar energy has become an ideal substitute for electrification with no limitation of sun radiation and less constrain of location. Apart from the PV thermal system that is traditionally popular in remote and rural areas for a long period of time [38], the PV power generation section could be a future trend in these remote and poor areas as the cost of the PV products has been falling dramatically [39].

In general, this section presented the historical conjuncture of projects, and the following part would mainly focus on the current situation of PVPA projects in China including the developing policies.

\subsection{PVPA current status and future plan}

China, as indicated in Figure 1, enjoys abundant solar resources, especially in southwestern areas, with the average solar radiation of more than $1100 \mathrm{kWh} / \mathrm{m} 2$. The other direction on the graph, the right axis, presents the current situation (number of poor villages) and their distribution in poverty areas in the 12th five-year plan. From the graph we could see that provinces with relatively large population of poverty tend to receive better sun radiation, which provide a suitable condition for the PVPA projects, providing physical feasibility and convenience.

The above-mentioned advantages and physical feasibility catalyzed the PVPA projects and the relevant working program to be established by the central government, thus in 2014, the National Energy Administration (NEA) and the Poverty Alleviation Office of China under the State Council proposed the 
PVPA projects for the first time [40]. With careful investigation and picking the poverty information as well as the solar radiation data, the pilot PVPA projects were launched with altogether $5.16 \mathrm{GW}$, in which $2.98 \mathrm{GW}$ were the ground-mounted centralized large scale systems, spreading in 14 provinces such as Shandong, Hebei, Anhui, and Jiangxi, covering 0.556 million poor residents accordingly where the solar radiation was the priority taken into consideration [41]. In such projects, the supporting policies from both the central government and the local government were crucial, especially the local government. For example, the subsidy in Hebei province was $0.2 \mathrm{RMB} / \mathrm{kWh}$ while in Shanxi, this figure was 0.1 million RMB per $20 \mathrm{~kW}[42,43]$. However, the provinces with high solar curtailment ratio were excluded in the PVPA program such as Qinghai and Ningxia, where the limitation of solar curtailment should be achieved first.

\section{$4 \quad$ Supporting recommendations}

policies

and

Figures and tables, as originals of good quality and well contrasted, are to be in their final form, ready for reproduction, pasted in the appropriate place in the text. Try to ensure that the size of the text in your figures is approximately the same size as the main text (10 point). Try to ensure that lines are no thinner than 0.25 point.

Fig. 1. Caption of the Figure 1. Below the figure.

\subsection{Supporting policies}

The supporting policies from either central government or the local government plays one of the most critical roles in the PVPA projects, yet no consensus has been reached on the classification of the policies. One of the classification method presented by Zhang, Chen and Tao is highly praised in the Chinese academic circle, categorizing the PVPA policies into the direct provision of financial loans and services by government, allowances and subsidy, contractual outsourcing and so on [44]. Chen, in 2004, classified the policies into market-oriented instruments, business administration techniques and social measures [45]. And Tao then argued that the policy instruments included five types of instruments: economic, administration, managerial, political and social instruments [46]. Although the above-mentioned policy classifications have widely adopted when studying the PVPA projects, they still seem to be too extensive or unsystematic or overlapping. As a result, we can use the idea which Rothwell and Zegveld first rose in 1985 to classify the basic policies into three categories: a supply type, a demand type and an environmental type [47]. Table 1 illustrates the PVPA policies and Table 2 classified those instruments in those three types. We can see that the demand type is underdevelopment compared to the other two. Detailed speaking, there are altogether 25 supply-type policy instruments, constituting around one third of the total quantity. The second class, the environmental type, occupies as high as $52 \%$ of all the policy instruments, and the exact number is 39 in all. The last one, the demand type, which only contains 11 kinds of PVPA policy instruments, accounts for only $14.67 \%$ of the whole policy package. Among all the three categories, an interesting discovery was found that government prefers the following three policy instruments: goal planning $(22 \%)$, financing support $(18.67 \%)$ and infrastructure construction (14.66\%), which accounts for the three highest proportion among all the policy instrument, followed by three evenly distributed ones namely capital investment, legal regulation and trans-regional/transdepartment cooperation. Apart from these obvious tendencies, there is only one tax-related policy within the environment type policy instruments in 2013. It is indicated that the VAT shall be immediately returned to the taxpayers who self-sale the electric power products using solar energy within the time range of October 1, 2013 to December 31, 2015. This policy considerably reduced the heavy tax burden of those low-income families and at the same time increased their income directly.

Evidently, the current PVPA policies emphasized on the strategic goals and financial support sectors, and the Chinese government has shown a relatively strong preference on the supply type and environment type policy instruments. However, for the supply and environment types, there is room for improvements. The dearth of supply type policy instruments implies that the PVPA in China faces some uncertainties, which the central government should perfect it as soon as possible. While at the same time, the deficiency in supply type instruments indicates that the government's direct production factors into PVPA projects is incomplete.

Table 1. Policy documents related to PVPA projects.

\begin{tabular}{|c|c|c|c|c|}
\hline No. & Documents & Agency & Year & Purpose \\
\hline 1 & $\begin{array}{c}\text { Circular on the } \\
\text { VAT Policy of PV- } \\
\text { based Power } \\
\text { Generation }\end{array}$ & $\begin{array}{l}\text { Ministry } \\
\text { of Finance }\end{array}$ & 2013 & $\begin{array}{c}\text { Tax } \\
\text { preference }\end{array}$ \\
\hline 2 & $\begin{array}{l}\text { Several Proposals of } \\
\text { State Council on } \\
\text { Promoting the } \\
\text { Healthy } \\
\text { Development of the } \\
\text { PV Industry }\end{array}$ & $\begin{array}{l}\text { The State } \\
\text { Council }\end{array}$ & 2013 & $\begin{array}{l}\text { Promotin } \\
\mathrm{g} \text { the } \\
\text { healthy } \\
\text { developm } \\
\text { ent of PV } \\
\text { industry }\end{array}$ \\
\hline 3 & $\begin{array}{c}\text { Provisional } \\
\text { Measures of } \\
\text { Administration over } \\
\text { Distributive PV } \\
\text { projects }\end{array}$ & NEA & 2013 & $\begin{array}{l}\text { PV } \\
\text { Construct } \\
\text { ion }\end{array}$ \\
\hline 4 & $\begin{array}{l}\text { Circular on Exerting } \\
\text { the Function of } \\
\text { Prize Leverage to } \\
\text { Promote the } \\
\text { Healthy } \\
\text { Development of PV } \\
\text { industry }\end{array}$ & NEA & 2013 & $\begin{array}{l}\text { Promotin } \\
\text { g the } \\
\text { healthy } \\
\text { developm } \\
\text { ent of PV } \\
\text { industry }\end{array}$ \\
\hline 5 & $\begin{array}{c}\text { Circular on Steadily } \\
\text { Boosting Rural }\end{array}$ & $\begin{array}{l}\text { The State } \\
\text { Council }\end{array}$ & 2014 & $\begin{array}{c}\text { Rural } \\
\text { Poverty }\end{array}$ \\
\hline
\end{tabular}




\begin{tabular}{|c|c|c|c|c|c|c|c|c|c|}
\hline & $\begin{array}{l}\text { Poverty Relief } \\
\text { Development by }\end{array}$ & & & Relief & & construction in 2015 & & & \\
\hline & $\begin{array}{l}\text { Innovative } \\
\text { Mechanism }\end{array}$ & & & & \multirow{3}{*}{16} & Proposals on & \multirow{3}{*}{ NEA } & \multirow{3}{*}{2015} & \multirow{3}{*}{$\begin{array}{l}\text { Promotin } \\
\text { g the } \\
\text { healthy } \\
\text { developm } \\
\text { ent }\end{array}$} \\
\hline 6 & $\begin{array}{c}\text { Provisional } \\
\text { Measures for Grid } \\
\text { Connection of } \\
\text { Newly-built Power } \\
\text { Supply }\end{array}$ & NEA & 2014 & PV power & & $\begin{array}{l}\text { Application of } \\
\text { Advanced PV } \\
\text { Techniques and } \\
\text { Products and }\end{array}$ & & & \\
\hline \multirow[b]{2}{*}{7} & Work Program on & \multirow[b]{2}{*}{ NEA } & \multirow[b]{2}{*}{2014} & \multirow[b]{2}{*}{$\begin{array}{l}\text { Construct } \\
\text { ion }\end{array}$} & & $\begin{array}{l}\text { Industrial } \\
\text { Upgrading of PV }\end{array}$ & & & \\
\hline & $\begin{array}{l}\text { based Poverty } \\
\text { Relief Project }\end{array}$ & & & & \multirow{3}{*}{17} & $\begin{array}{l}\text { Implementation } \\
\text { Proposals of }\end{array}$ & \multirow{3}{*}{ NEA } & \multirow{3}{*}{2015} & \multirow{3}{*}{$\begin{array}{c}\text { Poverty } \\
\text { alleviatio } \\
\mathrm{n}\end{array}$} \\
\hline 8 & $\begin{array}{l}\text { Notice on issuing } \\
\text { the annual } \\
\text { construction scale } \\
\text { of PV power } \\
\text { generation in } 2014\end{array}$ & NEA & 2014 & $\begin{array}{l}\text { Construct } \\
\text { ion }\end{array}$ & & $\begin{array}{c}\text { Administration on } \\
\text { Accelerating the } \\
\text { Energy } \\
\text { Development }\end{array}$ & & & \\
\hline \multirow[t]{2}{*}{9} & \multirow{2}{*}{$\begin{array}{l}\text { Guiding Opinions } \\
\text { on Offering } \\
\text { Desirable Financial } \\
\text { Service to Poverty } \\
\text { Relief Development } \\
\text { in an All-round } \\
\text { Way }\end{array}$} & \multirow{2}{*}{$\begin{array}{l}\text { The } \\
\text { people's } \\
\text { bank of } \\
\text { China }\end{array}$} & \multirow[t]{2}{*}{2014} & \multirow[t]{2}{*}{$\begin{array}{l}\text { Financial } \\
\text { Support }\end{array}$} & & $\begin{array}{l}\text { Poverty-stricken } \\
\text { Areas and Boosting } \\
\text { the Storming of } \\
\text { Poverty Elimination }\end{array}$ & & & \\
\hline & & & & & 18 & $\begin{array}{l}\text { Provisional } \\
\text { Measures for } \\
\text { Snecial Fund }\end{array}$ & Ministry & 2015 & $\begin{array}{c}\text { Capital } \\
\text { investmen }\end{array}$ \\
\hline \multirow[b]{2}{*}{10} & \multirow{2}{*}{$\begin{array}{l}\text { Programme for the } \\
\text { file and card } \\
\text { establishment to } \\
\text { Poverty Relief } \\
\text { Development }\end{array}$} & \multirow{2}{*}{ NEA } & \multirow[b]{2}{*}{2014} & \multirow{2}{*}{$\begin{array}{l}\text { Poverty } \\
\text { Identificat } \\
\text { ion }\end{array}$} & 10 & $\begin{array}{l}\text { Management of } \\
\text { Renewable Energy }\end{array}$ & of finance & 2015 & $\mathrm{t}$ \\
\hline & & & & & & $\begin{array}{c}\text { Program for } \\
\text { Compilation of PV- }\end{array}$ & & & \\
\hline \multirow[b]{2}{*}{11} & \multirow[b]{2}{*}{$\begin{array}{l}\text { The implementation } \\
\text { Plan for establishing } \\
\text { the Mechanism of } \\
\text { Precision Poverty } \\
\text { Alleviation }\end{array}$} & \multirow{2}{*}{$\begin{array}{l}\text { The state } \\
\text { council } \\
\text { leading } \\
\text { group } \\
\text { office of } \\
\text { poverty } \\
\text { alleviation } \\
\text { and } \\
\text { developm } \\
\text { ent }\end{array}$} & \multirow[b]{2}{*}{2014} & \multirow[b]{2}{*}{$\begin{array}{l}\text { Poverty } \\
\text { Identificat } \\
\text { ion }\end{array}$} & 19 & $\begin{array}{c}\text { Relief } \\
\text { Implementation } \\
\text { Scheme (Trial) } \\
\end{array}$ & NEA & 2015 & ion \\
\hline & & & & & 20 & $\begin{array}{c}\text { Circular on } \\
\text { Practically Ensuring } \\
\text { Desirable } \\
\text { Cooperation } \\
\text { between } \\
\text { Government and }\end{array}$ & $\begin{array}{l}\text { National } \\
\text { developm } \\
\text { ent and } \\
\text { reform } \\
\text { commissi }\end{array}$ & 2016 & $\begin{array}{c}\text { Financial } \\
\text { support }\end{array}$ \\
\hline \multirow[b]{2}{*}{12} & \multirow{2}{*}{$\begin{array}{l}\text { Opinions on } \\
\text { Reforming the } \\
\text { Management } \\
\text { Mechanism of } \\
\text { Special Financial } \\
\text { Fund to Poverty } \\
\text { Alleviation }\end{array}$} & \multirow[b]{2}{*}{$\begin{array}{l}\text { Ministry } \\
\text { of Finance }\end{array}$} & \multirow[b]{2}{*}{2014} & \multirow[b]{2}{*}{$\begin{array}{c}\text { Capital } \\
\text { investmen } \\
\mathrm{t}\end{array}$} & & $\begin{array}{c}\text { Field of Traditional } \\
\text { Infrastructures }\end{array}$ & on & & \\
\hline & & & & & 21 & $\begin{array}{l}\text { Guiding opinions on } \\
\text { developing } \\
\text { characteristic } \\
\text { industries to }\end{array}$ & $\begin{array}{l}\text { Ministry } \\
\text { of } \\
\text { agricultur }\end{array}$ & 2016 & $\begin{array}{l}\text { Poverty } \\
\text { alleviatio }\end{array}$ \\
\hline \multirow[b]{2}{*}{13} & \multirow{2}{*}{$\begin{array}{l}\text { Opinions on Further } \\
\text { Mobilizing All } \\
\text { Social Forces to } \\
\text { Participate in } \\
\text { Poverty Relief } \\
\text { Development }\end{array}$} & \multirow[b]{2}{*}{$\begin{array}{l}\text { The state } \\
\text { council }\end{array}$} & & & & $\begin{array}{c}\text { Poverty Eradication } \\
\text { in Poor Areas }\end{array}$ & $\mathrm{e}$ & & \\
\hline & & & 2014 & $\begin{array}{l}\text { Financial } \\
\text { support }\end{array}$ & 22 & $\begin{array}{c}\text { Proposals on } \\
\text { Exerting the } \\
\text { Function of Capital }\end{array}$ & $\begin{array}{l}\text { China } \\
\text { Securities } \\
\text { Regulator }\end{array}$ & 2016 & Statutory \\
\hline & $\begin{array}{l}\text { Proposals of } \\
\text { improving the } \\
\text { Economic and }\end{array}$ & & & & 22 & $\begin{array}{l}\text { National Strategy of } \\
\text { Poverty Relief } \\
\text { Storming }\end{array}$ & $\begin{array}{c}\mathrm{y} \\
\text { Commissi } \\
\text { on }\end{array}$ & 2016 & regulation \\
\hline 14 & $\begin{array}{l}\text { Social Development } \\
\text { performance } \\
\text { Assessment of the } \\
\text { party and } \\
\text { government leading } \\
\text { bodies and leading } \\
\text { cadres in poor }\end{array}$ & $\begin{array}{l}\text { The state } \\
\text { council }\end{array}$ & 2014 & $\begin{array}{l}\text { Assessme } \\
\text { nt of } \\
\text { poverty } \\
\text { relief }\end{array}$ & 23 & $\begin{array}{l}\text { Pilot Program for } \\
\text { Reforming the } \\
\text { Asset income from } \\
\text { Hydropower and } \\
\text { Mineral Resources } \\
\text { Development in } \\
\text { Poor Areas }\end{array}$ & $\begin{array}{l}\text { The State } \\
\text { Council }\end{array}$ & 2016 & $\begin{array}{c}\text { Income } \\
\text { distributio } \\
n\end{array}$ \\
\hline 15 & $\begin{array}{l}\text { counties } \\
\text { Notice on the } \\
\text { implementation plan } \\
\text { of PV power } \\
\text { generateon }\end{array}$ & NEA & 2015 & $\begin{array}{l}\text { Construct } \\
\text { ion }\end{array}$ & 24 & $\begin{array}{l}\text { Notice on matters } \\
\text { related to the } \\
\text { Integration of } \\
\text { Agricultural funds }\end{array}$ & $\begin{array}{l}\text { Ministry } \\
\text { of Finance }\end{array}$ & 2016 & $\begin{array}{c}\text { Financial } \\
\text { support }\end{array}$ \\
\hline
\end{tabular}




\begin{tabular}{|c|c|c|c|c|}
\hline & in Poverty Counties & & & \\
\hline 25 & $\begin{array}{l}\text { Proposals of the } \\
\text { CPC Central } \\
\text { Committee and the } \\
\text { State Council on } \\
\text { implementing the } \\
\text { New concept of } \\
\text { Development to } \\
\text { speed up } \\
\text { Agricultural } \\
\text { Modernization, and } \\
\text { achieve the goals of } \\
\text { a whole well-off } \\
\text { society }\end{array}$ & $\begin{array}{l}\text { The State } \\
\text { Council }\end{array}$ & 2016 & $\begin{array}{c}\mathrm{PV} \\
\text { agricultur } \\
\mathrm{e}\end{array}$ \\
\hline 26 & $\begin{array}{l}\text { National Plan for } \\
\text { Agricultural } \\
\text { Modernization } \\
(2016-2020)\end{array}$ & $\begin{array}{l}\text { Ministry } \\
\text { of } \\
\text { Agricultur } \\
\text { e }\end{array}$ & 2016 & $\begin{array}{l}\mathrm{PV} \\
\text { agricultur } \\
\mathrm{e}\end{array}$ \\
\hline 27 & $\begin{array}{l}\text { Notice on investing } \\
\text { the construction } \\
\text { conditions for PV } \\
\text { power generation }\end{array}$ & NEA & 2016 & $\begin{array}{l}\text { Construct } \\
\text { ion }\end{array}$ \\
\hline 28 & $\begin{array}{l}\text { Administrative } \\
\text { Measures for the } \\
\text { Full-amount } \\
\text { Indemnificatory } \\
\text { Purchase of } \\
\text { Renewable Energy } \\
\text { Power Generation }\end{array}$ & $\begin{array}{l}\text { Ministry } \\
\text { of Finance }\end{array}$ & 2016 & $\begin{array}{l}\text { Sales of } \\
\text { electric } \\
\text { power }\end{array}$ \\
\hline 29 & $\begin{array}{l}\text { Circular on the } \\
\text { Thirteenth Five- } \\
\text { Year Plan for } \\
\text { Poverty relief } \\
\end{array}$ & $\begin{array}{l}\text { The State } \\
\text { Council }\end{array}$ & 2016 & $\begin{array}{c}\text { Goal } \\
\text { planning }\end{array}$ \\
\hline 30 & $\begin{array}{l}\text { Some proposals of } \\
\text { the General Office } \\
\text { of the State Council } \\
\text { on improving the } \\
\text { supporting policy to } \\
\text { promote the } \\
\text { sustained increasing } \\
\text { of farmer's income }\end{array}$ & $\begin{array}{l}\text { The State } \\
\text { Council }\end{array}$ & 2016 & $\begin{array}{l}\text { Farmer's } \\
\text { income }\end{array}$ \\
\hline 31 & $\begin{array}{l}\text { Work program on } \\
\text { implementing } \\
\text { PVPA project }\end{array}$ & NEA & 2016 & $\begin{array}{l}\text { Construct } \\
\text { ion }\end{array}$ \\
\hline 32 & $\begin{array}{c}\text { Key points of } \\
\text { targeted Poverty } \\
\text { Alleviation and } \\
\text { counterpart support } \\
\text { in } 2016 \\
\end{array}$ & NEA & 2016 & $\begin{array}{c}\text { Construct } \\
\text { ion }\end{array}$ \\
\hline 33 & $\begin{array}{c}\text { Implementation } \\
\text { Opinions on } \\
\text { Financial Boosting } \\
\text { of Poverty } \\
\text { Elimination } \\
\text { Storming }\end{array}$ & $\begin{array}{l}\text { The } \\
\text { people's } \\
\text { bank of } \\
\text { China }\end{array}$ & 2016 & $\begin{array}{c}\text { Financial } \\
\text { support }\end{array}$ \\
\hline 34 & $\begin{array}{c}\text { Circular of National } \\
\text { Energy } \\
\text { Administration on } \\
\text { Actively } \\
\text { popularizing the } \\
\text { Mode of } \\
\text { Cooperation } \\
\text { between } \\
\text { Government and } \\
\text { Social Capital in the } \\
\text { Energy Field }\end{array}$ & NEA & 2016 & $\begin{array}{c}\text { Financial } \\
\text { support }\end{array}$ \\
\hline
\end{tabular}

\begin{tabular}{||c|c|c|l|l|}
\hline 35 & $\begin{array}{c}\text { Proposals on } \\
\text { Implementing } \\
\text { Poverty Relief of } \\
\text { PV-based Power } \\
\text { Generation }\end{array}$ & $\begin{array}{c}\text { National } \\
\text { Developm } \\
\text { ent and } \\
\text { Reform } \\
\text { Commissi } \\
\text { on }\end{array}$ & 2016 & $\begin{array}{c}\text { Sales of } \\
\text { electric } \\
\text { support }\end{array}$ \\
\hline 36 & $\begin{array}{c}\text { Administrative } \\
\text { Measures for the PV } \\
\text { Poverty Relief Loan } \\
\text { of Agricultural } \\
\text { Development Bank } \\
\text { of China (Trial) }\end{array}$ & $\begin{array}{c}\text { Agricultur } \\
\text { al } \\
\text { Developm } \\
\text { ent Bank } \\
\text { of China }\end{array}$ & 2016 & Financial \\
support
\end{tabular}

Table 2. Distribution of basic policy instruments.

\begin{tabular}{|c|c|c|c|}
\hline $\begin{array}{l}\text { Instrument } \\
\text { type }\end{array}$ & Instrument name & Total & Percentage \\
\hline 1 & $\begin{array}{l}\text { Support of scientific and } \\
\text { technical information }\end{array}$ & N/A & N/A \\
\hline 2 & Infrastructure construction & 11 & $14.67 \%$ \\
\hline 3 & Capital investment & 6 & $8 \%$ \\
\hline 4 & Educational cultivation & 2 & $2.67 \%$ \\
\hline 5 & Public service & 5 & $6.67 \%$ \\
\hline 6 & Goal programming & 17 & $22.67 \%$ \\
\hline 7 & Financing support & 14 & $18.67 \%$ \\
\hline 8 & Tax preference & 1 & $1.33 \%$ \\
\hline 9 & Statutory regulation & 7 & $9.33 \%$ \\
\hline 10 & $\begin{array}{l}\text { Protection of intellectual } \\
\text { property right }\end{array}$ & 1 & $1.33 \%$ \\
\hline 12 & Governmental procurement & 1 & $1.33 \%$ \\
\hline 13 & $\begin{array}{c}\text { Policy of electric power } \\
\text { sales }\end{array}$ & 4 & $5.33 \%$ \\
\hline 14 & $\begin{array}{l}\text { Trans-regional/trans- } \\
\text { depratmental copperation }\end{array}$ & 6 & $8 \%$ \\
\hline Total & $\mathrm{N} / \mathrm{A}$ & 75 & $100 \%$ \\
\hline
\end{tabular}

\subsection{Policy recommendations}

There are several suggestions and implications to the Chinese PVPA policies in order to realize the ambitious goal of eliminating poverty by 2020 .

Based on the previous analysis, we could safely indicate the results that: 1) three types of specific policy instruments are currently most popular: goal programming (accounts for $22.67 \%$ ), financing support (accounts for 18.67) and infrastructure construction (accounts for 14.64\%). 2) At present, the government 
emphasizes on the supply-type and the environment-type policies, with less attention on the demand-oriented policies. Moreover, the supply-oriented ones are not developed soundly.

Therefore, here are some policy recommendations for China:

Firstly, reduce the use of policy instruments regarding goal planning to a moderate level, and increase the economic ones properly. At the same time, the central government should enhance the policies pertaining to the sales of PV-generated power by either government procurement or encouraging the coordination with the traditional thermal power plants.

Secondly, financial incentives and financing support policy instruments should be emphasized to a greater extent as one of the most severe obstacle for the establishment of PVPA projects for the poverty people is lack of capital. China Central Television (CCTV), the main official broadcaster in China, reported in the end of 2016 that Ningxia's pilot PVPA projects faced serious delay in construction due to lack of financing support, and for those who have already established the roof-top PV stations successfully, they received 300 RMB annually from the project developer, or just $10 \%$ of the suggested number in the NEA policy indication.

Besides the above-mentioned financial difficulties, the accountability of the PVPA project is another important issue and challenge for the policy-makers to consider. The poor residents from remote and poverty areas tend to have little knowledge and information regarding the PVPA projects as well as the subsidiaries and supporting policies, thus they could be classified as the "passive beneficiaries", the ones that would only get benefit if noticed or informed. They have hardly any negotiation power towards other stakeholders such as local government, project developers, grid companies or policy banks, thus the supervision toward the appropriate distribution of the benefit returns from the PVPA projects within the whole project cycle matters a lot. Since the policy-maker and the initiator of the PVPA projects, the NEA, is not the direct monitor of those powerful parties such as local governments, it is quite a large challenge for them to regulate the benefit distribution so that the goal of the PVPA projects, the poverty alleviation, could implement with satisfied outcome.

\section{Conclusion and Discussion}

Based on the context analysis, we firstly studied the historical conjuncture of the PVPA projects and the related policies, indicating that the three main reasons of why the PVPA projects are presented now is due to the poverty situation in rural areas in China, the crossroad faced by Chinese PV enterprises and the rural electrification issue. Then the current status of PVPA projects in China, especially the policy instruments, and conclusion could be made that among the three classifications of the PVPA polices in China, namely the supply-type, the environment-oriented and the demandtype, Chinese central government prefers the first two categories, and the three most popular specific instruments are goal planning, infrastructure construction as well as the financing support. However, there are still some difficulties in the PVPA projects and suggestions were made to cope with the obstacles.

\section{References}

Here are some examples:

1. Zhang, J.B., 1995. On the distribution of solar energy resources. T. South. Farm Mach. 3 (2323)(in Chinese).

2. Oh, K., Yoo, J., 2014. Is the technology in renewable energy converging among countries? Using the patent data of OECD. Environ. Resour. Econ. Rev. 23 (1), 67-89.

3. Long, X.L., Naminse, E.Y., Du, J., Zhuang, J., 2015. Nonrenewable energy, renewable energy, carbon dioxide emissions and economic growth in China from 1952 to 2012. Renew. Sustain. Energy Rev. 52, 680-688.

4. Utria, B.E., 2004. Ethanol and gelfuel: clean renewable cooking fuels for poverty alleviation in Africa. Energy Sustain. Dev. 9 (3), 107-114.

5. Bhutto, A.W., Karim, S., 2007. Energy-poverty alleviation in Pakistan through use of indigenous energy resources. Energy Sustain. Dev. 3 (4), 58-67.

6. Openshaw, K., 2010. Biomass energy: Employment generation and its contribution to poverty alleviation. Biomass Bioenerg. 34 (3), 365-378.

7. Urge-Vorsatz, D., Herrero, S.T., 2012. Building synergies between climate change mitigation and energy poverty alleviation. Energy Policy 49, 83-90.

8. Chakravarty, S., Tavoni, M., 2013. Energy poverty alleviation and climate change mitigation: is there a trade off? Energy Econ. 40, S67-S73.

9. Mohan, G., Longo, A., Kee, F., 2018. The effect of area based urban regeneration policies on fuel poverty: evidence from a natural experiment in Northern Ireland. Energy Policy 114, 609-618.

10. Liu, Y.S., Li, Y.H., 2017. Revitalize the world's countryside. Nature 17, 275-277.

11. Li, J.X., 2016. Innovate agriculture science, and drive targeted poverty alleviation. Iss. Agr. Econ. 6, 4-8 (in Chinese).

12. Jennifer, A., Smallholder, B., 2012. Irrigation as a poverty alleviation tool in sub-Saharan Africa. World Dev. 40, 110-123.

13. Ge, J.P., Lei, Y.L., 2013. Mining development, income growth and poverty alleviation: a multiplier decomposition technique applied to China. Resour. Policy 38, 278-287.

14. World Bank, Access to Electricity (\% of Population), (2012) available at: http://data.worldbank.org/indicator/EG.ELC.ACCS. ZS ?locations $=\mathrm{CN}$. 
15. National Bureau of Statistics, China Statistics Yearbook 2015, (2016) available at:http://www.stats.gov.cn/tjsj/ndsj/2015/indexch.ht $\mathrm{m}$ (in Chinese).

16. J.B. Knight, L. Song, The Rural-Urban Divide: Economic Disparities and Interactionsin China, Oxford University Press, Oxford, 1999.

17. Xinhua News Agency, The Wealth Disparity is Closing to the 'Red Line' in China,(2010) Available at: http://news.xinhuanet.com/fortune/201005/10/c_1283123.htm (in Chinese).

18. CPC, State Council, Resolutions on Battling Poverty, (2015) Available at: http://www.nea.gov.cn/201512/08/c_134895715.htm (in Chinese).

19. S. Geall, W. Shen, Gonbuzeren, Solar energy for poverty alleviation in China: State ambitions, bureaucratic interests, and local realities. Energy Research \& Social Science 41 (2018) 238-248.

20. State Council, Opinions on Deepening the Institutional Reforms on Income Distribution. State Council Policy No. 2016(6), (2013) available at: http://www.gov.cn/zwgk/2013-

02/05/content_2327531.htm (in Chinese).

21. Chyxx. Development and characteristic analysis of the PV industry in China in 2008-2014. 〈http://www.chyxx.com/industry/201510/350574.ht $\mathrm{ml}\rangle$.

22. ChinaPower. A whole analysis of the development of PV industry in China. 〈http:// www.chinapower.com.cn/newsarticle/1230/new123 0319.asp >

23. Ofweek. Analysis of the development situation of China's PV industry. 〈http://solar. ofweek.com/2013-12/ART-260006-842028758557.html〉; 2014.

24. S. Zhang, P. Andrews-Speed, M. Ji, The erratic path of the low-carbon transition in China: evolution of solar PV policy, Energy Policy 67 (2014) 903-912.

25. F. Urban, S. Geall, Y. Wang, Solar PV and solar water heaters in China: different pathways to low carbon energy, Renew. Sustain. Energy Rev. 64 (2016) 531-542.

26. State Council, Opinions on Deepening the Institutional Reforms on Income Distribution. State Council Policy No. 2016(6), (2013) available at: http://www.gov.cn/zwgk/201302/05/content_2327531.htm (in Chinese).

27. National Energy Administration, Statistics on Solar Energy in 2015, (2016) Available at: http://www.nea.gov.cn/201602/05/c_135076636.htm (in Chinese).

28. National Energy Administration, The 13th Five Year Plan for the Electricity Industry, (2016) available at: http://www.nea.gov.cn/xwfb/20161107zb1/index. htm (in Chinese)
29. International Energy Agency, World Energy Outlook, (2016).

30. W. Shen, Who drives China's renewable energy policies? Understanding the role of industrial corporations, Environ. Dev. 21 (2016) 87-97.

31. National Energy Administration, Mission Accomplished for Resolving the Energy Access Problem for All Chinese, (2015) available at: http://www.nea.gov.cn/201512/24/c_134948340.htm (in Chinese).

32. National Energy Administration, Notifications on Issuing of the Guidelines for SEPAP Implementation, (2015) available at: http://www.nandudu.com/article/18495 (in Chinese).

33. National Energy Administration, Opinions on Accelerating the Construction of Energy Projects in Poverty Areas to Support the Battle of Eradicating Poverty, (2015) available at: http://www.escn.com.cn/news/show-294412.html (in Chinese).

34. Z. Bie, Y. Lin, An overview of rural electrification in China: history technology, and emerging trends, IEEE Electrif. Mag. 3 (1) (2015) 36-47.

35. Z. Bie, Y. Lin, An overview of rural electrification in China: history technology, and emerging trends, IEEE Electrif. Mag. 3 (1) (2015) 36-47.

36. H. Huang, Z. Yan, Present situation and future prospect of hydropower in China, Renew. Sustain. Energy Rev. 13 (6-7) (2009) 1652-1656.

37. W. Peng, J. Pan, Rural electrification in China: history and institutions, China World Econ. 14 (1) (2006) 71-84.

38. L. Zhang, Z. Yang, B. Chen, G. Chen, Rural energy in China: pattern and policy, Renew. Energy 34 (12) (2009) 2813-2823.

39. J. Byrne, A. Zhou, B. Shen, K. Hughes, Evaluating the potential of small-scale renewable energy options to meet rural livelihoods needs: a GIS-and lifecycle costbasedassessment of Western China's options, Energy Policy 35 (8) (2007) 4391-4401.

40. National Energy Administration of the People's Republic of China, State Council of the People's Republic of China. Work program on implementation of PV poverty alleviation project; 2014.

41. National Development and Reform Commission, State Council of the People's Republic of China, National Energy Administration of the People's Republic of China, China Development Bank, Agricutural Development Bank of China. Notice on implementing PV poverty alleviation projects; 2016.

42. Northwest China Energy Regulatory Bureau of National Energy Administration of the People's Republic of China. Supervision report on gridconnected new energy sources in Shaanxi, Ningxia and Qinghai power grids. 2017. 
43. Government of Shanxi province. Interim Measures for the Administration of PV Poverty Reduction Projects in Shanxi Province 2016.

44. Zhang, C.F., Dang, X.Y., 2001. Public Management. Renmin University of China Press, Beijing (in Chinese).

45. Chen, Z.M., 2004. Research on government tools and improvement of government management. Chin. Admin. 6, 43-48 (in Chinese).

46. Tao, X.R., 2006. Public Policy. Dongbei University of Finance \& Economics Press, Dalian (in Chinese).

47. Rothwell, R., Zegveld, W., 1985. Reindusdalization and Technology. Logman Group Limited, London. 